American Journal of Applied Sciences 8 (11): 1116-1121, 2011

ISSN 1546-9239

(C) 2011 Science Publications

\title{
Ecotourism Development in Recreational Forest Areas
}

\author{
Md. Anowar Hossain Bhuiyan, Chamhuri Siwar, \\ Shaharuddin Mohamad Ismail and Rabiul Islam \\ Institute for Environment and Development, \\ Faculty of Centre for Graduate Management \\ University Kebangsaan Malaysia, \\ 43600 UKM, Bangi, Selangor, Darul Ehsan, Malaysia
}

\begin{abstract}
Problem statement: This study explored the issues and strategies of ecotourism development in recreational forest areas of Malaysia. There are a number of forest recreational areas and reserves. The recreation forests are designated and managed under the forestry department. These recreational areas of scenic beauty comprise about $0.05 \%$ of the total forest reserves in Peninsular Malaysia. Ecotourism should be set in natural areas with special biological, ecological, or cultural interest. Objective: The aim of this study was to illustrate the potentiality to develop ecotourism in the recreational forests of ECER, especially in Sekayu recreational forest area. Approach: The data for analysis was obtained from the secondary sources. Results: The study showed that there was opportunities and potentialities in the recreational forests of ECER for ecotourism development. These was suitable location, availabilities of recreational forests, attractive natural beauty, pollution free environment, limited natural disaster and infrastructure development. There was some strategiesecological integrity, tourism urbanization, forest tourism development, government role and tour operator initiatives could be followed for ecotourism development in the recreational forests of this region. Conclusion: Appropriate policy, initiative and tourism development activities can be ensured ecotourism development in the recreational forests of Malaysia as well as ECER. In Sekayu, community participation must be increased for the sustainable ecotourism development in the forest.
\end{abstract}

Key words: Ecotourism development, recreational forest areas, appropriate policy, tourism development activities, recreational forests, community participation, tourism urbanization, ecological integrity

\section{INTRODUCTION}

Forest areas and nature protection in developing countries are often seen as recreational assets and there are generally few opportunities to earn income from them. In addition, governments in developing countries are finding to provide sufficient funding for the maintenance of their national parks and forest areas (Krug, 2000). Tourism offers the potential to provide economic development, through the provision of increased income and employment, conserving nature and funding for maintenance of national parks. Many developing countries, for example, Kenya, successfully use the attractions of nature in promoting tourism in protected and forest areas (Nepal, 2000; Tosun, 1998). Tourism should contribute to economic diversification of a region through establishment of a range of ecologically sustainable tourist and recreational areas and activities based on the region's natural and man-made attractions' (WADPUD, 1994). Natural resources at tourism destinations and sustainable tourism development are growing topics in the tourism literature (Hassan, 2000). Forest areas are important places for the protection of ecological systems and natural resources as well as for the provision of recreational and tourism opportunities for the people (Boyd, 2006). Growing concern for conservation and the well-being of the environment over the past two decades has brought about a closer relationship between the environment and tourism (Reynolds and Braithwaite, 2001).

Forest areas have important environmental values and they are often established in sensitive environments. The World Tourism Organization

Corresponding Author: Md. Anowar Hossain Bhuiyan, Institute for Environment and Development,

Faculty of Centre for Graduate Management, University Kebangsaan Malaysia,

43600 UKM, Bangi, Selangor, Darul Ehsan, Malaysia 
defines sustainable tourism as one that improves the quality of life of local communities, provides high quality experience for tourists and maintains the quality of the environment on which they both depend (McIntyre et al., 1993). Forest parks have the potential and perhaps even the obligation to actively promote sustainable development through recreation and tourism (Machlis and Field, 2000). There are a number of potential environmental effects that can arise from tourism that degrade the natural assets of forest areas. These factors include overcrowding, inappropriate infrastructure development, various forms of pollution and inappropriate human behavior that impacts on forest area's fauna and flora (McNeely et al., 1992).

Forests in Southeast Asia are valued for their high biodiversity, ecosystem and commercially important value (Kummer and Turner, 1994). Malaysia has a number of forest recreational areas and reserves. Recreation forest is a forest designated for public recreational use which was conceptualized during the First Malaysian Plan period (1966-1970). The Recreation Forests are designated and managed under the Department of Forestry. These recreational areas of scenic beauty comprise about $0.05 \%$ of the total permanent forest reserves in Peninsular Malaysia. Recreation forests of Malaysia attract a large number of visitors from home and abroad.

Ecotourism relates to an experience in remote or natural areas that fosters an understanding and appreciation of the need to conserve the natural environment in a way that sustains the resources, culture, the economy and the local community (Fennell, 2008). Defined ecotourism as 'An experience with a focus on the natural and cultural environment, an ecologically sustainable activity, an activity with a predominant educative and interpretive program and an activity that contributes to local community groups and projects and to the conservation of the surrounding environment'. According to Orams (1995), ecotourism consists of the following components. Conservation benefits, the nature-based activity, the setting and economic and social benefits. Ecotourism has emerged sustainable tourism as one solution to help protect the ecological and cultural resources of tourism sites,provide local economic opportunity and give travelers greater environmental awareness (Bhuiyan et al., 2011a). Ecotourism should benefit conservation through improved management of visited natural areas and ecosystems. The ecotourism activity should have a strong focus on learning through interpretation of local ecology, ecosystem and cultural heritage. Effectiveness of ecotourism as a socioeconomic and environmental tool is depending on equitability of income distribution among the local communities (Bhuiyan et al., 2011b). Finally, ecotourism should be set in natural areas with special biological, ecological, or cultural interest (Furze et al., 1996).

The East Coast Economic Region (ECER) consists of three states- Kelantan, Terengganu, Pahang and District of Mersing in Johor. It covers 51\% of the land area of Peninsular Malaysia and represents $14 \%$ of the national population. The ECER established under an Act of Parliament. This region is empowered to provide for coordination between Government entities in the promotion of trade, investment, tourism and development activities within this region. Tourism has long been an important economic driver in the region, attracting both local and foreign visitors to the region's enchanting natural and cultural attractions. The region is well-known for its natural assets-unspoilt beaches, serene, coral-ringed islands as well as lush rainforests, cool clean rivers, recreational forest and calming highlands ECER Master Plan. There are 42 recreational forest areas situated in ECER. These recreational forests are suitable for ecotourism development in this region. Sekayu is the largest recreational forest in Terengganu. The forest becomes famous to the visitors' for its natural beauties. The aim of this study is to examine the potentiality to develop ecotourism in the recreational forests of ECER, especially in Sekayu recreational forest area. The study also analyzes the considerable issues and strategies of ecotourism development in this recreational forest.

\section{MATERIALS AND METHODS}

Data attainment: The study is conducted in University Kebangsaan Malaysia, Bangi since January, 2011 to April, 2011. The data for analysis is derived from the secondary sources. The significant manipulations for acquired data are tourism on East Coast Economic Region (ECER) and Sekayu Recreational Forest of Terengganu in Malaysia. The corresponding outcomes are demonstrated from the analysis of collected data.

Recreational forest: The concept of Recreation Forest was described in the National Forestry Policy (Forestry Department) as an objective of the permanent forest reserve. With the National Forestry Act (Forestry Department), the objectives of recreation forests were strengthened under section 10 of the Act where the permanent reserve forest can be classified for various uses. Recreational forest used as the conservation of adequate forest areas for recreation, education and the protection of the country's unique flora and fauna. Its 
purposes are to conserve enough area as places for recreation, ecotourism and to enhance the public's awareness on forestry. Recreation Forests can be described as areas designated for not only picnicking and outdoor activities but also conservation of local flora and fauna as well as areas where environmental education can be conducted. Recreation Forests set up specifically for educational purposes. However, it is observed that currently Recreation Forests are mainly serving for recreational activities. The increase in recreational needs could be due to the rising number of the population, increase of leisure and money, as well as the upward trend in nature appreciation (Yahha, 1999).

Sekayu recreational forest: Sekayu Recreational Forest was established in 1974 and officially launched in 1985. It is located within Hulu Terengganu forest reserve at Kuala Berang of Terengganu. The total area of the recreational forest is 30 hectares. Seven cascades waterfalls which become the natural swimming pools make it a famous retreat for visitors. Sekayu is rich with Dipterocarp species such as Meranti and Damar Hitam (Shorea Species), Keruing (Dipterocarpus species). The recreational park is well facilitated with public facilities such as shelters, changing room, chalets and rest house, providing for visitors' convenience. Sekayu Waterfall is said to be one of the most comprehensive picnicking and trekking area in the state. There is a fruit orchard, a mini zoo, a bird park and a flower garden near the waterfall. This recreational park has become one of the promoted agro and ecotourism destinations for the state.

\section{RESULTS}

Table 1 shows the number of recreational forests in Peninsular Malaysia. There are 26 recreational forest situated in Pahang, which is the second largest amount among the states of Peninsular Malaysia. After Pahang, Terengganu and Kelantan are second and third position respectively in the number of recreational forest.

Table 2 shows the domestic tourist arrival in Sekayu Recreational Forest. The total domestic tourists' arrival was 134,337 and 203,947 in 2006 and 2010 respectively. The annual growth rate was 7.1 in 2010 . The total domestic tourists' arrival will be 287,097 and 424,856 in 2015 and 2020 respectively. The annual growth rate will be reached at 9.6 in 2020 .

Table 3 reveals the international tourist arrival in Sekayu Recreational Forest. The total international tourists' arrival was 1,418 and 1,140 in 2006 and 2010 respectively. The annual growth rate was 6.1 in 2010 . The total international tourists' arrival will be 1536 and 2149 in 2015 and 2020 respectively.
Figure 1 reveals the number of Recreational Forest areas in Peninsular Malaysia by the year. The first recreational forest has developed in Kedah on 1967. In 1970 , the number of recreational forests was only 3 and end of the year 2009 it reached 125. The highest number of recreational forests was developed during the 1980-1990 period.

Figure 2 presents the forecast tourists arrivals for Malaysia and ECER. Domestic tourists' arrival in ECER was 8.3 and 11.4 million in 2005 and 2010 respectively. Again, foreign tourists' arrival was 1.9 and 2.9 million in the same period. In the table forecasts domestic tourists' arrival will be 15.6 and 21.4 million in 2015 and 2020 respectively. On the other hand, foreign tourists' arrival of ECER will be 4.7 and 7.4 million in 2015 and 2020 for the same period.

Table 1: Number of recreational forest areas in Peninsular Malaysia

\begin{tabular}{ll}
\hline Name of state & $\begin{array}{l}\text { Number of } \\
\text { recreational forest }\end{array}$ \\
\hline Johor & 08 \\
Kedah & 27 \\
Kelantan & 03 \\
Melaka & 04 \\
Negeri Sembilan & 12 \\
Pahang & 26 \\
Perak & 15 \\
Perlis & 02 \\
Pulau Pinang & 03 \\
Selangor & 10 \\
Terengganu & 13 \\
Kuala Lumpur & 02 \\
\hline
\end{tabular}

Source: Forestry Statistics Peninsular Malaysia, 2009

Table 2: Domestic tourist arrival in Sekayu recreational forest

\begin{tabular}{lll}
\hline Year & Total tourists & $\begin{array}{c}\text { Annual average growth } \\
\text { rate }(\% \text { per year })\end{array}$ \\
\hline 2006 & 134.337 & --- \\
2007 & 181.000 & 34.7 \\
2008 & 181.275 & 0.2 \\
2009 & 190.465 & 5.1 \\
2010 & 203.947 & 7.1 \\
$2015(\mathrm{e})$ & 287.097 & 8.2 \\
$2020(\mathrm{e})$ & 424.856 & 9.6 \\
\hline
\end{tabular}

Source: Compiled by the authors (e-estimation)

Table 3: International tourist arrival in Sekayu Recreational Forest

\begin{tabular}{lcc}
\hline Year & Total tourists & $\begin{array}{c}\text { Annual average growth } \\
\text { rate }(\% \text { per year })\end{array}$ \\
\hline 2006 & 1.418 & --- \\
2007 & 1.010 & -28.8 \\
2008 & 1.256 & 24.4 \\
2009 & 1.074 & -14.5 \\
2010 & 1.140 & 6.1 \\
$2015(\mathrm{e})$ & 1536.000 & 6.9 \\
$2020(\mathrm{e})$ & 2149.000 & 8.0 \\
\hline
\end{tabular}

Source: Compiled by the authors (e- estimation) 


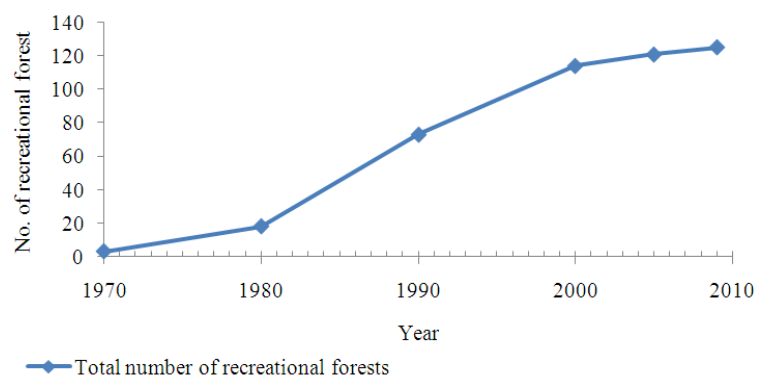

Fig. 1: Recreational forest areas in Peninsular Malaysia

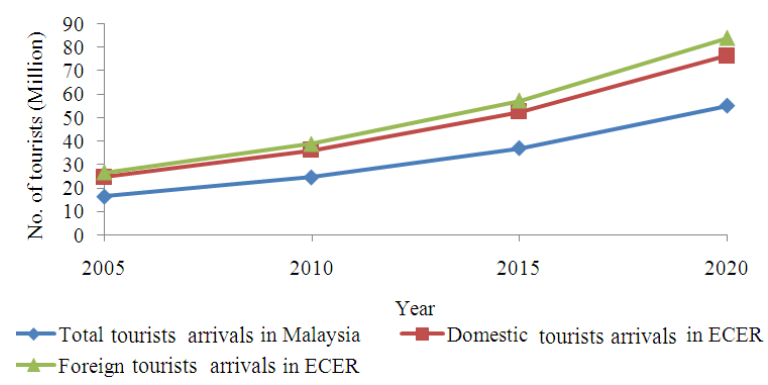

Fig. 2: Tourists arrivals for Malaysia and ECER

\section{DISCUSSION}

The recreational forests of ECER are famous for their natural attractions. The forests may be unique places to the tourists' for their flora and fauna, ecology and biodiversity. So, these recreational forests can be developed as suitable ecotourism destination. There are some potentialities are remaining in the recreational forests of ECER for ecotourism development.

Suitable location: All recreational forests of ECER are situated in permanent forest reserved. This forest reserve are protected and maintained by the forest department. As a result, they keep the natural attractions of recreational forests which are very important for ecotourism development.

Availabilities of recreational forests: There are 42 recreational forests are located in the ECER among the 125 of Peninsular Malaysia. Taman Negeri and Taman Rimba Kenong, largest two recreational forests of Peninsular Malaysia are situated in this region. Ecotourism development in the forest areas can enhance the tourism activities in ECER.

Attractive natural beauty: Recreational forests of ECER are full of natural beauties and resources. Local flora and fauna, natural environment, ecology and biodiversity are main characteristics of the forests. All of these attract the tourists' to enhance their environmental awareness.

Pollution free environment: The recreational forests of ECER are mostly free from environmental pollution. Most of the recreational forests have waterfall. Water of these falls' is clean and fresh. This is a lucrative attraction to the tourists.

Limited natural disaster: Natural disasters are main causes for destruction and degradation of forest areas. Many tourism places of the world have been damaged for natural disaster. ECER is almost free from huge natural disaster. Limited natural disasters are helpful for ecotourism development in the recreational forests of this region.

Infrastructure development: The Malaysian government spends considerable amounts of fund for infrastructure development in this region. For the infrastructure efficiency, ecotourism development easily occurs in the recreational forests of ECER.

Ecotourism development in the recreational forests can ensure the economic development of ECER. At the same time it is helpful to keep the forest areas from degradation. There are some strategies can be followed for ecotourism development in the recreational forests of this region.

Ecological integrity: Ecological integrity is necessary for ecotourism development in the recreational forest areas. Tourism site's natural beauty and number of visitors must be controlled for ecological sustainability. A growth in visitor numbers to a forest area may threats to the ecological integrity of resources or even result in the transformation of a natural environment in an area. For example, Banff National Park in Canada has suffered a serious environmental deterioration as a result of human impacts (Boyd, 2006).

Tourism urbanization: Communities of a region were largely urbanized as a result of ecotourism development. The surrounding areas of ecotourism site experienced rapid and uncontrolled development for tourism activities. Environmental problems associated with tourism urbanization such as pollution, crime and overcrowded condition are remaining in the Yellowstone region (Ansson, 1998). For this region, sustainable ecotourism development must be ensured in the recreational forests of ECER.

Forest tourism development: The increase of visitors in a forest area prompted the increase in facilities and 
services to meet the needs of tourists. Many tourists chose to stay in or adjacent to the forest during their visitations. The investors to build more facilities in the forest area and consequently increased the transformation of the forest environment.

Government role: Government has played a crucial role in planning, regulating and coordinating the ecotourism development in the recreational forest areas. The planning is carried out at the national level with policy makers and experts from the central government being the major actors. Under the federal government's policy of alleviating poverty through tourism development ecotourism has come to be regarded as an economic growth point.

Local govt. role: In order to promote the ecotourism development in the recreational forest areas, local governments have adopted a policy of privilege for investors, including low prices for leasing land.

Tour operator: Tour operators have been playing an important role in bringing more tourists to the recreational forests since the involvement stage onwards, particularly at the consolidation stage when tourists swarmed to the forests as packaged tours.

Ecotourism development in Sekayu recreational forest: Sekayu Recreational Forest is located $16 \mathrm{~km}$ from the town of Kuala Berang through the main road of Kuala Berang-Sekayu, $56 \mathrm{~km}$ from Bandar Kuala Terengganu. The site is the largest visitors' attracting recreational forest area in Terengganu. The park has RM1 entry fee for the visitors. But the last two year, the entry fee has been prohibited. The site is open for the tourists from early morning to evening. There are sufficient numbers of staffs in the forest for maintaining the site and tourism activities. The site is well kept and clean. The direction signs to show within the forest are clear and helpful for the tourists. Print and electronic materials of the attraction are available in Terengganu and all over the Malaysia. There are sufficient places for parking and to move and relax in the forest site. The environment and physical attraction of the site is attractive to the visitors. There are good sightseeing and comfortable facilities available in the forest. The site provides environmental awareness and educational opportunities to the tourists. There are sufficient prayer places and toilets in the site. All of the above mentioned features are helpful to the ecotourism development in the Sekayu recreational forest.

In spite of huge opportunities, Sekayu has some short coming for ecotourism development. The staff of this site needed additional training for adequate knowledge on tourist attraction. The information site is not well decorated and informative for the visitors. In this site, the information about sustainable use of attraction not provided to the tourists. There is not enough accommodation arrangement in site the forest for the tourists. There is not enough food stall in and outside the forest area. The visitors bring their food from outside the forest area. The local communities of the forest areas are not hugely involved with tourism related employment. They are not enough conscious regarding the ecotourism development in the forest area.

\section{CONCLUSION}

Ecotourism is one of the fastest and growing tourism segmentation in the world today. This has limited negative impact and environmental well being. Many developing country give emphasize to develop ecotourism in their country for economic development and create employment opportunities. Forest areas are important asset for any country. The balance of environment, ecology and biodiversity of a country depends on the amount of forest areas. Ecotourism development is suitable for recreational forest area, due to its' environmental well being. Ecotourism can prevent the forest degradation and keep the forest pollution free. ECER covers the larger part of land in Peninsular Malaysia. The Malaysian government gives emphasize on the economic development of this region for ensuring the sustainable regional development. Ecotourism is one of the major ways for the economic enhancement of the region. Malaysian government has formulated National Ecotourism Plan in 1996 for the ecotourism development. Under the plan, the government gives attention to the natural attractions and reserve forests for the ecotourism development. The one-third numbers of recreational forests of Peninsular Malaysia are situated in the ECER. All of these forests can be developed as sustainable ecotourism destination, which ensure the economic development of this region as well as employment opportunities. The federal and local government can attract the local and foreign investment for the ecotourism activities in the recreational forests of this region. Again, proper policy, initiative and tourism development activities can be ensured ecotourism development in the recreational forests of Malaysia as well as ECER. In Sekayu, community participation must be increased for the sustainable ecotourism in the forest. Without local people participation, sustainable ecotourism development is not possible. 


\section{ACKNOWLEDGEMENT}

Financial assistance provided by the Arus Perdana (AP) Research Grant, Institute for Environment and Development, University Kebangsaan Malaysia (Ref. No. UKM-AP-PLW-04-2010) headed by Prof Chamhuri Siwar is gratefully acknowledged.

\section{REFERENCES}

Ansson, R.J., 1998. Our National Parks-overcrowded, underfunded and besieged with a myriad of vexing problems: How can we best fund our imperiled national park system. J. Land Use Environ. Law, 14: $1-51$.

Bhuiyan, M.A.H., C. Siwar, S.M. Ismail and R. Islam, 2011a. The Role of Government for Ecotourism Development: Focusing on East Coast Economic Region. J. Soc. Sci., 7: 557-564. DOI: 10.3844/jssp.2011.557.564

Bhuiyan, M.A.H., C. Siwar, S.M. Ismail and R. Islam, 2011b. The role of home stay for ecotourism development in east coast economic region. Am. J. Applied Sci., 8: 540-546. DOI: 10.3844/ajassp.2011.540.546

Boyd, S.W., 2006. The TALC model and its application to national parks. In: The Tourism Area Life Cycle: Applications and modifications, R.W. Butler (Eds.). Channel View Publications, Clevedon, ISBN: 1845410254, pp: 119-138.

Fennell, D.A., 2008. Ecotourism. 3rd Edn., Routledge, London, ISBN-10: 0415429315, pp: 282.

Furze, B., T.D. Lacy and J. Birckhead, 1996. Culture, Conservation and Biodiversity: The Social Dimension of Linking Local Level Development and Conservation through Protected Areas. John Wiley, Chichester, ISBN: 0471949027, pp: 269.

Hassan, S.S., 2000. Determinants of market competitiveness in an environmentally sustainable tourism industry. J. Travel Res., 38: 239-245. DOI: 10.1177/004728750003800305

Krug, W., 2000. Nature tourism and protected area pricing: Lessons Learned from Africa. Proceedings of the Design and Management of Forest Protected Areas: Papers Presented at the Beyond the Trees Conference, May 8-11, World Wildlife Fund Forests for Life Campaign: Godalming, UK., Bangkok, Thailand, pp: 159-173.
Kummer, D.M. and B.L. Turner, 1994. The human causes of deforestation in Southeast Asia. BioSci., 44: 323-323.

Machlis, G.E. and D.R. Field, 2000. National Parks and Rural Development: Practice and Policy in the United States. 1st Edn., Island Press, Washington, DC., ISBN-10: 155963815X, pp: 323.

McIntyre, G., A. Hetherington and E. Inskeep, 1993. Sustainable Tourism Development: Guide for Local Planners. 1st Edn., World Tourism Organization, Madrid, Spain, ISBN-10: 9284400384, pp: 166.

McNeely, J.A., J.W. Thorsell and H. CeballosLascurain, 1992. Guidelines: Development of NATIONAL parks and Protected Areas for Tourism. 1st Edn., World Tourism Organization, UNEP, Paris, ISBN: 9284400260, pp: 53.

Nepal, S.K., 2000. Tourism in protected areas: The Nepalese Himalaya. Ann. Tourism Res., 27: 661681. DOI: 10.1016/S0160-7383(99)00105-X

Orams, M.B., 1995. Towards a more desirable form of ecotourism. Tourism Manage., 16: 3-8. DOI: 10.1016/0261-5177(94)00001-Q

Reynolds, P.C. and D. Braithwaite, 2001. Towards a conceptual framework for wildlife tourism. Tourism Manage., 22: 31-42. DOI: 10.1016/S02615177(00)00018-2

Tosun, C., 1998. Roots of unsustainable tourism development at the local level: The case of Urgup in Turkey. Tourism Manage., 19: 595-610. DOI: 10.1016/S0261-5177(98)00068-5

WADPUD, 1994. Central Coast regional strategy: A Strategy to Guide Land Use in the Next Decade: Prepared for the Central Coast Planning Study Steering Committee as Part of the Strategic Planning Program of the State Planning Commission. 1st Edn., The Department, Perth, W.A., ISBN: 0730953297, pp: 113.

Yahha, N.A., 1999. Environmental Settings of Three Recreation Forests and Their Effects on Visitors' Perception. PhD Thesis, Universiti Putra Malaysia. 